\title{
Coexisting Cholinergic and Parahippocampal Degeneration: A Key to Memory Loss in Dementia and a Challenge for Transgenic Models?
}

\author{
Jean-Christophe Cassel ${ }^{\mathrm{a}}$ Chantal Mathis $^{\mathrm{a}}$ Monique Majchrzak $^{\mathrm{a}}$ \\ Pierre-Henri Moreau $^{\mathrm{a}} \quad$ John C. Dalrymple-Alford ${ }^{\mathrm{b}}$ \\ a LINC UMR 7191, Université Louis Pasteur, CNRS, Institut Fédératif de Recherche IFR 37, GDR CNRS 2905,

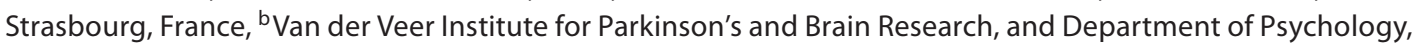 \\ University of Canterbury, Christchurch, New Zealand
}

\section{Key Words}

Alzheimer's disease $\cdot$ Lesion models $\cdot$ Cholinergic basal forebrain $\cdot$ Entorhinal cortex $\cdot$ Memory $\cdot$ Transgenic models

\begin{abstract}
One century after Alzheimer's initial report, a variety of animal models of Alzheimer's disease (AD) are being used to mimic one or more pathological signs viewed as critical for the evolution of cognitive decline in dementia. Among the most common are, (a) traditional lesion models aimed at reproducing the degeneration of one of two key brain regions affected in AD, namely the cholinergic basal forebrain (CBF) and the transentorhinal region, and (b) transgenic mouse models aimed at reproducing AD histopathological hallmarks, namely amyloid plaques and neurofibrillary tangles. These models have provided valuable insights into the development and consequences of the pathology, but they have not consistently reproduced the severity of memory deficits exhibited in AD. The reasons for this lack of correspondence with the severity of expected deficits may include the limited replication of multiple neuropathology in potentially key brain regions. A recent lesion model in the rat found that severe memory impairment was obtained only
\end{abstract}

when the two traditional lesions were combined together (i.e. conjoint CBF and entorhinal cortex lesions), indicative of a dramatic impact on cognitive function when there is coexisting, rather than isolated, damage in these two brain regions. It is proposed that combining AD transgenic mouse models with additional experimental damage to both the $\mathrm{CBF}$ and entorhinal regions might provide a unique opportunity to further understand the evolution of the disease and improve treatments of severe cognitive dysfunction in neurodegenerative dementias.

Copyright $\odot 2008$ S. Karger AG, Basel

\section{From Alzheimer to Transgenic Mice}

On November the 3rd 1906, at a local psychiatry meeting in Germany (the 37th Meeting of Southwest German Psychiatrists, Tübingen), Aloïs Alzheimer (1864-1915) presented one of the most important observations in brain science and published these findings the following year [1]. As is well known, he had found two neuropathological abnormalities in the cortex of a 56-year-old dementia patient, Auguste Deter. The first neuropathological feature was the presence of intracellular neuro-

\section{KARGER}

Fax +4161306 1234 E-Mail karger@karger.ch www.karger.com
(C) 2008 S. Karger AG, Basel

$1660-2854 / 08 / 0055-0304 \$ 24.50 / 0$

Accessible online at:

www.karger.com/ndd
Jean-Christophe Cassel, LINC UMR 7191 Université Louis Pasteur, CNRS

Institut Fédératif de Recherche 37, 12 rue Goethe

FR-67000 Strasbourg (France)

Tel. +33 390241 952, Fax +33 390241958

E-Mail jean-christophe.cassel@linc.u-strasbg.fr 
fibrillary tangles (NFTs), now known to result from hyperphosphorylation of the cytoskeletal protein tau [2], which is involved in microtubule assembly and stabilization. The second hallmark was the presence of what are now called senile plaques, which are extracellular deposits of $\beta$-amyloid peptide $(A \beta)$ that result from the abnormal cleavage of the amyloid protein precursor (APP) [see, for example 2, 3]. The two hallmarks described by Alzheimer allow postmortem confirmation of a prior Alzheimer's dementia, but the clinical course of the condition itself is characterized by a protracted decline in functional independence through progressive worsening of a broad range of higher cognitive functions, of which severe deficits in long-term episodic memory and spatial disorientation are of the most prominent neurobehavioral signs [4]. Some recent evidence suggests that neuritic plaques are more influential than tangles in the earlier stages of Alzheimer's disease (AD) [e.g. 5, but see 6]. The modern era of interest in the pathological events that lead to this dementia began in the mid-1970s with a focus on the degenerative changes in cholinergic basal forebrain $(\mathrm{CBF})$ projections $[7,8]$. The most significant of these findings was that a decline in neocortical cholinergic markers in the temporal lobes correlated strongly with the degree of overall cognitive impairment [9] and the association between cholinergic dysfunction and dementia continues to receive support [e.g. 10-15, but see 16]. Parallel clinical and experimental work led to the influential cholinergic hypothesis of Bartus et al. [17] of geriatric memory dysfunction based on the idea of a causal link between CBF degeneration and the early memory deficits that provide the essential cognitive signature of dementia of the Alzheimer type [18]. The cholinergic hypothesis provided the rationale for developing cholinomimetic therapy, which remains the frontline drug treatment for dementia, although its efficacy has been less promising than initially expected [3, 19-22]. However, the pioneering work by Perry et al. [9] has been based on information derived from AD patients with severe dementia. Actually, neither patients at risk for $\mathrm{AD}$ (MCI) nor mild AD patients appear to have marked depletion of cholinergic indicators in the neocortex [e.g. 2, 23 vs. 24-26]. Some MCI patients even show upregulation of cholinergic function, which may reflect early adaptive mechanisms in response to ongoing neurodegenerative processes [26].

More recently, the retrohippocampal region in the medial temporal lobe has been proposed as the brain area that shows some of the earliest signs of neurodegeneration. Given this region's complex interconnections with the hippocampal formation, it is presumed that it must play an essential role in the emergence of prominent episodic memory deficits [27]. In particular, early atrophy and hypometabolism of the transentorhinal region has been highlighted by postmortem and recent in vivo brain imaging studies of dementia patients [e.g. 28-30]. Moreover, changes in the entorhinal cortex, specifically, have been found to be good predictors for the conversion from MCI to AD [14, 31-34]. In addition to the atrophy of medial temporal lobe structures, afferent and efferent pathways and functionally connected regions contribute to the memory impairments found in patients at the earliest stages of $\mathrm{AD}[30,35]$. For example, a recent study by Nestor et al. [36] is particularly revealing in showing that medial temporal lobe degeneration, in isolation, does not explain the marked episodic memory impairment characteristic of AD. While these authors focused on the importance of limbic-diencephalic neurocircuitry beyond the medial temporal lobe, their findings point to the more general importance of considering multiple, conjoint degenerative processes in explaining severe episodic memory loss. We suggest that the recent approach focusing almost exclusively on the CBF or the entorhinal cortex region with respect to memory decline in $\mathrm{AD}$ ignores the potential influence of changes to multiple neural systems. Specifically, it may be the concurrent degeneration in both the CBF and the entorhinal cortex, and the loss of their functional interactions that provides a major reason for the severity of memory decline in dementia. While it is clear that $\mathrm{AD}$ represents a complex disorder, and the role of neuropathological changes are central to an understanding of $\mathrm{AD}$, the prominence of cognitive deficits must remain a central focus of attention because it is the cognitive and behavioral deficits that pose the daily handicap for the patient and their relatives.

In the following brief review, we summarize evidence on some of the more common rodent models of $\mathrm{AD}$, including those using transgenic manipulations to induce amyloid and/or tangle histopathology in mice, and those using classic lesion methodologies to mimic either $\mathrm{CBF}$ or entorhinal cortex degeneration. The main contributions and limitations of each approach to understand $\mathrm{AD}$ pathology and cognitive changes are reviewed. It is clear that the extent of cognitive impairment expressed in most single lesion or transgenic models appears to be relatively limited, even with extensive lesions or heavy amyloid or tangle histopathology. We then briefly describe the dramatic memory deficits obtained in a recent rat $\mathrm{AD}$ model, which examined the effects of combined CBF and 
entorhinal cortex lesions to reproduce the effects of conjoint degenerative changes in these regions. The success of the latter strategy prompts us to propose the advantage of combining the strengths of this multiple lesion model with those of transgenic mouse models to optimize new models of AD.

\section{Benefits and Limits of Transgenic Mouse Models Bearing Plaques and/or NFTs}

The aim of transgenic manipulations in mice is to model the fundamental neuropathology underlying AD and develop molecular treatment strategies aimed at reversing this neuropathology [for more detailed reviews, see for example 37-39]. Recent advances in the molecular neurobiology and genetics of AD have engendered several mouse lines bearing plaques and/or NFTs, which resulted in valuable progress in understanding some key steps in the development of AD-like pathophysiology and its consequences for brain function. For example, single and multiple transgenic models have proven to be powerful tools to study both the individual role of several ADrelated proteins (e.g. ApoE, BACE-1, presenilin-1) in the abnormal metabolism of APP, $A \beta$ and tau, as well as the synergistic relationships between $A \beta$ and tau pathologies [e.g. 24, 40-44]. However, a further motivation in creating these lines was to evaluate the impact of either amyloid plaques, NFTs or both on memory function as a means to clarify their involvement in the cognitive symptomatology of AD. Table 1 summarizes the neuropathology and cognitive deficits reported for some of the more representative $\mathrm{AD}$ transgenic mouse models. The first transgenic models, which were mainly plaque-bearing mice overexpressing human APP (h-APP) mutated genes, have now been characterized in terms of cognitive ability at different developmental stages [e.g. 37, 38, 45] (table 1).

Unfortunately, some mouse lines, such as PDAPP mice, display age-independent memory deficits in some tasks and age-dependent deficits in other tasks, the latter deficits emerging well before amyloid plaques are detected. The age-independent deficits are presumably related to early neurodevelopmental abnormalities, consistent with a role of APP in brain ontogeny [e.g. 41, 136]. By contrast, many other h-APP transgenic lines, such as APP23 mice and Tg 2576 mice, show age-dependent amyloid deposits and memory deficits, which is more desirable for an animal model of AD. Of particular interest in modeling the progressive changes in $\mathrm{AD}$, these models also of- ten display some behavioral deficits before the onset of plaque formation. Such findings pointed to the deleterious effects of the soluble forms of $A \beta$ (e.g. $A \beta$ oligomers) on synaptic and cognitive function, which suggests that soluble $\mathrm{A} \beta$ may play a role in early $\mathrm{AD}$ cognitive impairments $[25,40,42,93,127,137,138]$. The major problem with the h-APP transgenic models is, however, that even the oldest mice with a severe amyloid burden may show greater than expected improvements in spatial learning tasks, such as the water maze or the Barnes maze [e.g. 54, 119]. Deficits in spatial working memory and spatial reference memory tasks are important because they provide useful animal analogues of AD-related impairments in episodic memory and spatial disorientation [139]. However, even the same transgenic mouse model may produce mixed findings, sometimes even when the same task is used (memory is impaired in some of the tasks and not in others or, using the same task, memory is impaired in some studies and not in others; table 1). For instance, PSAPP have been reported to exhibit impaired acquisition in a water-maze task but normal retention, or normal acquisition but then impaired retention, or alterations of both (table 1), and the same remark applies to NFT transgenic models, such as JNPL3 mice, in the same task [109].

Thus, current transgenic mouse models of $\mathrm{AD}$ are extremely valuable, but have certain limitations because they reproduce only partially the progression, severity and range of deficits in spatial memory tasks used to model those found in AD. As it is known that degeneration of the CBF and the entorhinal regions are both involved in the $\mathrm{AD}$ cognitive decline, it is pertinent to examine whether similar cholinergic and transentorhinal neurodegenerative events are found in transgenic mouse models.

As shown in table 1, however, most research on transgenic mice has focused on pathological signs in the hippocampus and the whole neocortical mantle, rather than in the transentorhinal region even though the latter shows the earliest evidence for neurodegeneration in $\mathrm{AD}$ [e.g. 29]. A few studies have shown some histopathologi$\mathrm{cal}$ and functional alterations in the entorhinal region of transgenic mouse lines, such as Tg 2576 or PSAPP mice $[42,52,140,141]$ (table 1). However, no quantitative evidence for cell loss or hypometabolism in the entorhinal cortex has been reported in transgenic mouse models yet $[142,143]$. In contrast to the paucity of data concerning the entorhinal cortex, the cholinergic system of several h-APP transgenic mice has been examined more frequently, although not systematically, most probably be- 
cause of the popularity of the cholinergic hypothesis of AD dementia. Most h-APP transgenic mice do show some alterations of cholinergic markers, although these are mainly restricted to the hippocampus and the cortex, which are the target structures of the basal forebrain projections $[50,51,85,138,142,144]$ (table 1). The disruption of their cholinergic inputs is usually explained in terms of the deleterious effect of local (target) amyloid load, which perturbates cholinergic presynaptic terminals and fibers $[87,140,142,144]$. Within the basal forebrain, reduced size of cholinergic cells or weakened cholinergic enzyme activities have been observed in two but not all transgenic mouse models [51, 142]. Moreover, the few studies that have tried to quantify the cholinergic neurons in the basal forebrain did not report a significant loss of cell bodies [e.g. 73]. Clearly, such weak cholinergic neuropathology fails to replicate that seen in dementia, which in turn might be one reason for the incomplete correspondence between the expected cognitive phenotype in old h-APP transgenic mice when modeling deficits found in $\mathrm{AD}$ patients. This lack of cholinergic neuron loss may be related to compensatory effects of the APP transgene, too short life span of the mouse for development of a complete neuropathologic scheme or resistance of the mouse basal forebrain to $A \beta$ neurotoxicity. With regard to NFT models, it is interesting that some show a general atrophy of the forebrain, which suggests a significant cell loss in this area, but it is not yet known whether this atrophy includes any substantial cholinergic cell loss per se [106]. Of more direct relevance, multiple transgenic mice expressing both amyloid plaques and NFTs do show evidence of neuronal loss in the entorhinal cortex (table 1). Evidently, further neuroanatomical and behavioral data are needed to establish their complete neuropathological scheme and try to relate it to the extent of their cognitive impairment.

In conclusion, transgenic mouse models of $\mathrm{AD}$ have enabled considerable progress in understanding the genesis and consequences of the amyloid and/or NFT burden, but they have thus far provided little specific evidence on the influence of regional pathology. Many of the approaches in transgenic mice have tried to focus on possible relationships between the two neuropathological hallmarks of AD and the cognitive phenotype, but only a few of them have tried to establish a more direct connection between the neurodegenerative consequences of the transgene and the cognitive phenotype. Thus transgenic mice studies could focus more specifically on regional neurodegenerative changes and behavior, particularly the $\mathrm{CBF}$ and the transentorhinal region.

Alzheimer's Disease, Neuropathology and Animal Models

\section{Lesions of the CBF or Lesion of the Entorhinal Cortex as Models of AD? Combining Both Lesions Provides a Better Model}

By contrast with transgenic models, models based on a traditional lesion approach can provide a more direct test of the critical importance of one or more degenerating regions as a basis for severe memory loss in dementia. Initially, the proposed relationship between cholinergic dysfunction and $\mathrm{AD}$ or age-related memory alteration was supported by experimental studies using animal models based on either systemically administered anticholinergic drugs or nonspecific lesions of the basal forebrain region. The fundamental basis of the cholinergic hypothesis faltered, however, when evidence emerged from a series of experimental studies that used more selective, even if extensive, immunotoxic cholinergic lesions of the basal forebrain in rats [e.g. 15, 16]. Contrary to expectations, these selective cholinergic lesions more consistently induced impairments in attention rather than memory, or they produced deficits on some learning tasks that provided ambiguous models of episodic memory. These newer observations were useful in terms of characterizing cognitive decline related to dementia, because dementia entails deficits well beyond any isolated memory impairment, but they conflict with the notion of the key importance of the CBF in episodic memory deficits. Deficits in attention were evident in animal lesion studies that damaged the nucleus basalis magnocellularis, the source of cholinergic afferents of the cortical mantle [e.g. 43, 145, 146]. Conversely, cholinergic lesions in the septohippocampal system did not reliably alter attention [e.g. 147], but, beside a few exceptions showing clear-cut memory deficits, they also generally failed to consistently induce dramatic effects on memory function [e.g. 16; but see 147]. It is noteworthy that these findings were apparent even with massive (>90\%) depletion of cholinergic markers such as choline acetyltransferase or acetylcholinesterase in the cortical mantle and/or the hippocampus [e.g. 15, 16]. Clearly, the manner in which cholinergic damage can account for memory impairment is an unresolved issue.

Similar conclusions can be drawn from lesions made in the transentorhinal region. Indeed, it is interesting that while fiber-sparing damage to the perirhinal and even the entorhinal cortex may result in some memory impairment, these deficits are seldom as dramatic as might be expected on the basis of the neural connectivity of this region with the hippocampus or the severity of memory impairment found in dementia patients [139].

Neurodegenerative Dis 2008;5:304-317 
Table 1. Summary of the main physiopathological alterations in the cortex, cholinergic basal forebrain and hippocampus, and cognitive status reported in the most frequent transgenic models of $\mathrm{AD}$ (references in square parentheses)

\begin{tabular}{lllll}
\hline $\begin{array}{l}\text { Transgenic } \\
\text { mouse model } \\
\text { (name) }\end{array}$ & $\begin{array}{l}\text { Gene } \\
\text { expressed }\end{array}$ & Amyloid deposits & NFTs & $\begin{array}{l}\text { Neuropathology } \\
\text { (cortex, hippocampus) or physiopathological alterations }\end{array}$ \\
\hline APP23 & $\begin{array}{l}\text { APP Swe Mut } \\
\text { cDNA }\end{array}$ & $\begin{array}{l}\text { Yes (Ctx, Hp) } \\
\text { Onset between the age of } \\
12 \text { and 18 months [46] }\end{array}$ & $\begin{array}{l}\text { No (but hP-Tau is present) } \\
\text { [e.g. 46] }\end{array}$ & $\begin{array}{l}\text { Cell loss in CA1 (no loss in Ctx) [46] } \\
\text { Fiber distortion in Hp plaque vicinity + aberrant sprouting in Hp [47] } \\
\text { Reduction of synaptic transmission in the Hp, but LTP is normal; } \\
\text { no effects in the frontal Ctx [48] } \\
\text { No change in the number of synaptophysin-positive terminals in the Ctx, } \\
\text { even at 24 months [49] }\end{array}$
\end{tabular}

\begin{tabular}{|c|c|c|c|c|}
\hline PDAPP & $\begin{array}{l}\text { APP minigene, } \\
\text { v717F mutation }\end{array}$ & $\begin{array}{l}\text { Yes (Ctx and Hp) } \\
\text { Onset between the } \\
\text { age of } 6 \text { and } 12 \text { months } \\
\text { [e.g. } 60-63 \text { ] }\end{array}$ & No (but hP-Tau is present) [62] & $\begin{array}{l}\text { Hypometabolism in several subcortical and cortical regions [64] } \\
\text { Reduced Hp volume, shortened corpus callosum, shrunken fornical } \\
\text { commissure [65-67] } \\
\text { Dentate gyrus shrinkage and reduced corpus callosum }[68,69] \\
\text { Amyloid deposits in Hp, especially in the projection areas of the EC [63] } \\
\text { Reduced spine density in Hp [70] } \\
\text { Reduced size of neurons in the locus coeruleus [71] } \\
\text { Reduced hippocampal neurogenesis [72] }\end{array}$ \\
\hline
\end{tabular}

\begin{tabular}{|c|c|c|c|c|}
\hline Tg2576 & APP Swe cDNA & $\begin{array}{l}\text { Yes }(\mathrm{Ctx}, \mathrm{Hp}) \\
\text { Onset between the age } \\
\text { of } 14 \text { and } 18 \text { months } \\
\text { [e.g. } 80 \text {, but see } 81 \text { ] }\end{array}$ & No (but hP-Tau is present) [e.g. 82] & $\begin{array}{l}\text { Decreased synapse density in dentate gyrus outer molecular layer [83] } \\
\text { No cell loss in CA1 [61] } \\
\text { Increased cholinergic synapse density in the frontal [84] and parietal } \\
\text { cortices [85] } \\
\text { Loss of dendritic spines in CA1 [70] } \\
\text { Normal ChAT activity in the frontolateral sensorimotor cortex [86] } \\
\text { Decreased spine density; no marked volumetric change in the Hp [87] }\end{array}$ \\
\hline
\end{tabular}

\begin{tabular}{|c|c|c|c|c|}
\hline $\begin{array}{l}\text { JNPL3, pR5, } \\
\text { also ALZ7 or } \\
\text { ALZ17 in } \\
\text { Spires and } \\
\text { Hyman[39] }\end{array}$ & $\begin{array}{l}4 \mathrm{R} \text { tau } \\
(4 \mathrm{R} \text { tau } \mathrm{P} 301 \mathrm{~L})\end{array}$ & No & $\begin{array}{l}\text { Yes (Ctx, Hp, amygdala, locus } \\
\text { coeruleus and substantia nigra) } \\
\text { Onset between the age of } 18 \text { and } \\
20 \text { months, but reports show earlier } \\
\text { appearance [101-104] } \\
\text { Injections of A } 42 \text { accelerates NFTs } \\
\text { formation [105] }\end{array}$ & $\begin{array}{l}\text { Reactive astrocytes in Ctx and amygdala; apoptosis in the somatosensory } \\
\text { Ctx, not in the Hp [105] } \\
\text { Brain atrophy, especially in the temporal lobe and } \mathrm{Hp} \text { (almost complete } \\
\text { loss of pyramidal neurons in CAl and CA2) }[103,106]\end{array}$ \\
\hline PSAPP & $\begin{array}{l}\text { Tg2 } 2576+\text { PS1 } \\
\text { M146L }\end{array}$ & $\begin{array}{l}\text { Yes (Ctx and Hp, } \\
\text { mainly C1A) } \\
\text { Onset between the } \\
\text { age of } 8 \text { and } 12 \text { weeks } \\
{[111-113]}\end{array}$ & $\mathrm{hP}-\mathrm{Tau}$ is present $[112]$ & $\begin{array}{l}\text { Decreased cholinergic synapses density in frontal Ctx [84] and Hp [85] } \\
\text { Minor loss of neurons in Ctx and Hp, mainly CA1 [112] } \\
\text { Reduced ChAT activity in occipital Ctx, but not the Hp [114] } \\
\text { Neuron-free holes in the Ctx [113] } \\
\text { Reduced mRNA of several synaptic plasticity-related genes in amyloid- } \\
\text { containing regions [115] } \\
\text { Marked reduction of number of CA1 neurons [116] } \\
\text { Normal LTP in Hp, but accelerated decay [117]; abnormal LTP [118] }\end{array}$ \\
\hline TAPP & $\begin{array}{l}\text { Tg2576x }+ \\
\text { JNPL3 }\end{array}$ & $\begin{array}{l}\text { Yes (Ctx, Hp) } \\
\text { Onset at } 6-7 \text { months, } \\
\text { numerous deposits at } \\
8.5-15 \text { months [43] } \\
\text { Amyloid burden increased } \\
\text { in Ctx and Hp, more in } \\
\text { females [125] }\end{array}$ & $\begin{array}{l}\text { Yes (olfactory, entorhinal Ctx, amyg- } \\
\text { dala, subiculum Hp-tau) } \\
\text { Onset at } 3 \text { months (in spinal cord } \\
\text { and pons in females at } 9-11 \text { months) } \\
{[43]}\end{array}$ & $\begin{array}{l}\text { Granulovacuolar degeneration in the subiculum [43] } \\
\text { Age-dependent reduction of the number of neurons in the Hp (CA1) [125] }\end{array}$ \\
\hline $3 x T g-A D$ & $\begin{array}{l}\text { APP (Swe mut) } \\
+ \text { PS } 1+\text { tau }\end{array}$ & $\begin{array}{l}\text { Yes }(\mathrm{Ctx} \text {, then } \mathrm{Hp}) \\
\text { Onset at about } 3 \text { months } \\
\text { [e.g. 126, 127] }\end{array}$ & $\begin{array}{l}\text { Yes (Hp then Ctx ) } \\
\text { Later onset, with tau apparent } \\
\text { at } 6 \text { months, undergoing hP much } \\
\text { later[e.g. 126] }\end{array}$ & LTP deficits in Hp before tangle and plaque formation [e.g. 128] \\
\hline
\end{tabular}

This table provides a nonexhaustive glance at the literature concerning the most frequent and/or some recent transgenic models of AD, with particular focus on neuropathological features in the cortex, the hippocampus, and more specifically in the cholinergic basal forebrain and the entorhinal cortex (when available). This table also briefly summarizes the various learning and memory deficits that could be identified (or not) so far, and in various tests, in each of these models.

$\mathrm{AChE}=$ Acetylcholinesterase; $\mathrm{Acq}=$ acquisition; Barnes = Barnes maze; ChAT = choline acetyltransferase; Cons = consolidation; $\mathrm{CTA}=$ conditioned taste aversion; Ctx = cortex; Ctxt fear Cond = contextual fear conditioning; $\mathrm{EC}=$ entorhinal cortex; Hp = hippocampus; hP-Tau = hyperphosphorylated Tau; H-W Mz = Hebb and Williams maze; LTP = long-term potentiation; $\mathrm{MW} \mathrm{Mz}=$ Morris water maze; NBM = nucleus basalis magnocellularis; .d. = not determined; NFTs = neurofibrillary tangles; Obj Rec = object recognition task; Pass Av = passive avoidance; PS1 = preseniline 1; RAD Mz = radial maze; Ret = retrieval; Ref Mem = reference memory; Swe Mut = Swedish mutation; Y-Mz = Y-maze alternation; T-Mz = T-maze alternation; vAChT = vesicular acetylcholine transporter; WM = working memory. 


\begin{tabular}{|c|c|c|}
\hline Cholinergic basal forebrain & $\mathrm{EC}$ & Memory deficits \\
\hline $\begin{array}{l}\text { AChE-positive fiber distortion in Ctx plaque vicinity [46] } \\
\text { Reduction of ChAT activity in the frontal Ctx, but no } \\
\text { change in the number of neurons in the NBM complex } \\
\text { [50] } \\
\text { AChE and ChAT activity reduced in the basal forebrain } \\
\text { [51] }\end{array}$ & $\begin{array}{l}\text { Qualitative loss of neurons in the } \\
\text { EC }[52,53] \\
\text { Reduction of ChAT-positive } \\
\text { boutons in the EC [50] }\end{array}$ & $\begin{array}{l}\text { Pass Av: Ret impaired at } 25 \text { months [54] } \\
\text { MW Mz: deficit in Acq before amyloid deposits [55]; attenuated by cholinesterase } \\
\text { inhibitors [56] } \\
\text { Plus-shaped water maze: impaired Acq, Cons still possible, WM impaired but not } \\
\text { obliterated [57] } \\
\text { RAD Mz: no deficit of WM [58] } \\
\text { 'Complex' Mz: impaired, but improved performance [58] } \\
\text { Barnes Mz: slower Acq, preserved Cons and Ret [59] }\end{array}$ \\
\hline $\begin{array}{l}\text { Hypometabolism in the septum [64] } \\
\text { Decreased cholinergic terminals in the Ctx and Hp, } \\
\text { but no loss of cholinergic neurons in the medial septum } \\
\text { and diagonal band of Broca; reduction of ChAT activity } \\
\text { in the cingulate Ctx [73] } \\
\text { Reduced acetylcholine release (microdialysis) in } \\
\text { hippocampus and attenuated responsiveness of the } \\
\text { release towards scopolamine; augmented high affinity } \\
\text { uptake of choline [74] }\end{array}$ & $\begin{array}{l}\text { A } \beta \text { deposits in molecular and } \\
\text { laminar layers II, III of the EC } \\
\text { (also in the Hp) [75] } \\
\text { No metabolic change in the } \\
\text { EC [64] }\end{array}$ & $\begin{array}{l}\text { Obj Recog: age-dependent deficit [64]; impairments also found in other studies } \\
\text { [e.g., 76]; no deficit in another study [77]. } \\
\text { RAD Mz: robust, age-dependent deficits in hetero- and homozygotes [64] } \\
\text { MW Mz: age-independent and age-dependent deficits [77]; marked deficit from } \\
\text { an early age onwards [60, see also 78] } \\
\text { Barnes Mz: age-dependent deficit [79] } \\
\text { Eyeblink conditioning: impaired [69] } \\
\text { Holeboard task: impaired [76] }\end{array}$ \\
\hline $\begin{array}{l}\text { Normal size of neurons in the medial septum and the } \\
\text { NBM [85] } \\
\text { Normal ChAT and AChE activity, vAChT and choline } \\
\text { uptake in Ctx, cerebellum, Hp and striatum [88] } \\
\text { Normal AChE and ChAT activity, reduced choline uptake, } \\
\text { reduced M1, M2 and nACh receptor binding in some re- } \\
\text { gions [89, 90] } \\
\text { Degeneration of ChAT-positive fibers in the Ctx [91] } \\
\text { Normal ChAT activity in frontal Ctx [86] } \\
\text { Reduced ChAT activity in pedonculopontine nucleus, but } \\
\text { not in laterodorsal tegmentum and medial septum [92] }\end{array}$ & $\begin{array}{l}\text { Decreased synapse density in } \\
\text { layers II and III [83] } \\
\text { Normal size or density of } \\
\text { cholinergic boutons in EC [85] } \\
\text { Perforant path stimulation- } \\
\text { induced LTP is altered in dentate } \\
\text { gyrus [87] }\end{array}$ & $\begin{array}{l}\text { MW Mz: age-dependent deficit, although ACq is not totally prevented; } \\
\text { CONS and RET seem impaired [80, 81,93, 94] or no deficit [95] } \\
\text { Barnes Mz: no deficit [96] } \\
\text { RAD Mz: no deficit of WM [97]; impaired WM in aquatic version of the task [94] } \\
\text { Y-Mz: alternation is at random [81, 94, 98,] } \\
\text { Obj Recog: impaired, especially after relocation [99] } \\
\text { Fear conditioning: contextual processing impaired [100]; severely impaired in an } \\
\text { age-dependent manner [87] }\end{array}$ \\
\hline No data found in the literature & $\begin{array}{l}\text { Tauopathy in the lateral EC } \\
{[102,104]} \\
\text { Tau inclusions in oligo- } \\
\text { dendrocytes of the EC [107] } \\
\text { Neurons with degenerated } \\
\text { cytoplasm and condensed nuclei } \\
\text { in the EC [103] }\end{array}$ & $\begin{array}{l}\text { CTA: impaired memory (with considerable heterogeneity) [103]; } \\
\text { accelerated extinction in another study [104] } \\
\text { MW Mz: normal Acq and Ret of Ref Mem [94, 103], but WM impaired [103]; Ref } \\
\text { Mem performance negatively correlated with the number of tau-positive neurons } \\
\text { in the Hp [94]; impaired [106, 108,]; normal Ref Mem and impaired WM [109] } \\
\text { Y-Mz: alternation rates are normal [94] } \\
\text { RAD Mz: deficit, but performance improves over trials; deficit more pronounced } \\
\text { with tangles vs. pretangles [103]; normal in aquatic version [94] } \\
\text { Obj Recog: normal performance at a short post-Acq delay (1 h), but not at a } \\
\text { longer one (3.5 h) [110] }\end{array}$ \\
\hline $\begin{array}{l}\text { Normal neuron size in medial septum and NBM [85] } \\
\text { Normal ChAT activity in medial septum, a trend to } \\
\text { reduction in NBM complex [114] }\end{array}$ & $\begin{array}{l}\text { Normal size or density of cholin- } \\
\text { ergic boutons in the EC [85] }\end{array}$ & $\begin{array}{l}\text { Barnes Mz: no deficit [119] } \\
\text { MW Mz: no deficit of Ref Mem during Acq, but some indication of altered Ret } \\
\text { [120]; impaired Acq but normal Ret [119]; impaired Acq and Ret [121,122,123]; } \\
\text { RAD Mz: impaired performance [120]; impaired WM in aquatic version of the } \\
\text { task [118, 119, 122, 124] } \\
\text { Y-Mz: normal alternation }[119,122] \\
\text { Obj Recog: impaired performance [120] } \\
\text { H-W Mz: marked deficit [116] }\end{array}$ \\
\hline No data found in the literature & $\begin{array}{l}\text { Amyloid deposits, NFTs and } \\
\text { granulovacuolar degeneration } \\
\text { [43] } \\
\text { Age-dependent reduction of the } \\
\text { number of neurons in the EC } \\
{[125]}\end{array}$ & $\begin{array}{l}\text { MW Mz: age-dependent impairment in visible platform task, impaired Acq in Ref } \\
\text { Mem and age-dependent Ret deficit [125] }\end{array}$ \\
\hline No data found in the literature & $\begin{array}{l}\text { Reduced number of Reelin-ex- } \\
\text { pressing pyramidal cells in EC; } \\
\text { reduced Reelin levels in Hp [129] } \\
\text { Early inflammation in EC [130] }\end{array}$ & $\begin{array}{l}\text { MW Mz: deficit (rescued by AF267B) [40, 131, 132]; females are transiently worse } \\
\text { than males [133] } \\
\text { Ctxt fear Cond: deficit (not sensitive to AF267B) }[131,133] \\
\text { T-Mz: WM deficit }[134,135]\end{array}$ \\
\hline
\end{tabular}




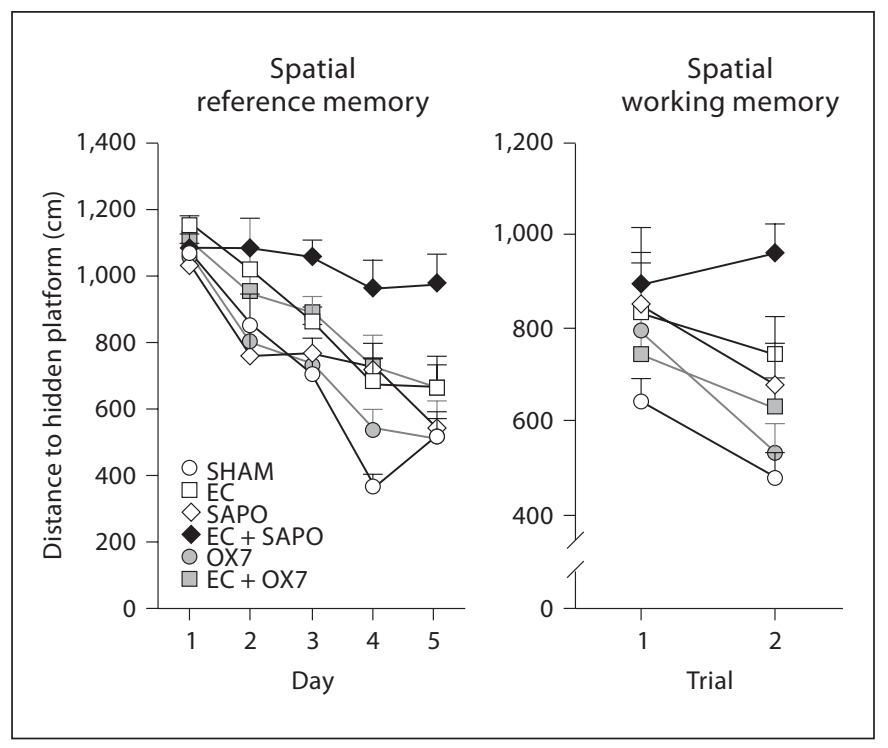

Fig. 1. Spatial reference memory and working memory performance in the Morris water maze in which the rat swims to the location of an escape platform hidden just beneath the opaque water surface. Performance is expressed as the mean distance $( \pm \mathrm{SEM})$ to find the hidden platform in rats subjected to shamoperations (SHAM), neurotoxic entorhinal cortex lesions (EC) or intracerebral injections of $192 \mathrm{IgG}$-saporin (SAPO) or OX7-saporin (OX7). EC + SAPO and EC + OX7 rats sustained combined lesions. Intracerebral 192 IgG-saporin severely depletes the CBF neurons, but can also influence the integrity of Purkinje cells in the cerebellum, as the latter also bear the target receptors of 192 IgG-saporin. OX7-saporin injections provide a selective control for the potential effects of cerebellar damage. For the reference memory task, rats were given 4 consecutive trials from different start points on each day and allowed to find the platform positioned always in the same location; reduction of the distance traveled demonstrates learning. Note the absence of improvement in $\mathrm{EC}+\mathrm{SAPO}$ rats. Such deficits failed to appear when the platform was visible (not shown). For the working memory test, the rats were given 2 consecutive trials (with different starting places) on each day, but the platform location was changed from day to day. This figure has been adapted from Traissard et al. [151].

Recent evidence suggests a more crucial role for the dorsolateral band of the entorhinal cortex, at least in spatial memory processes, but rats with such lesions are still able to learn a new spatial location in a water-maze task and their primary deficit concerns the failure to retrieve a location that had been acquired prior to lesion surgery [148].

This brief summary on the contribution of lesion approaches [for further details, see 15, 16, 149] leads to the conclusion that neurodegeneration in the transentorhinal region and isolated cholinergic depletion of the hip- pocampus (and/or cortex) are similarly insufficient to cause major memory deficits $[16,150]$. Although entorhinal cortex degeneration begins well before severe episodic memory loss or frank dementia become obvious, it is expected that substantial loss in this region would have a significant influence on memory. It remains, however, highly plausible that it is a combination of severe neurodegenerative changes in both the entorhinal cortex and the CBF that constitutes a central issue for episodic memory loss in $\mathrm{AD}$.

Evidence pertinent to this question has recently been published by Traissard et al. [151] in a study in which adult male rats were subjected to selective immunotoxic lesions of basal forebrain cholinergic neurons and fibresparing lesions of the entorhinal cortex, either separately or in combination. CBF lesions were made by intracerebroventricular injections of the low affinity nerve growth factor receptor-specific cholinergic immunotoxin 192 IgG-saporin [152, 153], while entorhinal cortex lesions were produced by multiple intraparenchymal injections of small amounts of N-methyl-D-aspartate. As illustrated in figure 1, rats with selective cholinergic damage alone showed little deficit on two widely used spatial memory tasks in the water maze, which tax reference and working memory, respectively, while those with entorhinal cortex lesions alone also showed only minor deficits. But there was a striking contrast in the rats that received the combination of 192 IgG-saporin and entorhinal cortex lesions as these rats showed a dramatic impairment on both spatial memory tasks and little evidence of being able to learn at all. These findings suggest that selective cholinergic lesions may severely tip the balance against an already failing medial temporal lobe memory system. Recent functional imaging studies suggest that many limbic and cortical brain regions in addition to the medial temporal lobe are associated with severe memory decline in dementia and its early progression [e.g. 36, 154, 155]. Nonetheless, we suggest that an improved understanding is required on the importance of the concurrent changes to these two key regions and their relationship to the dramatic memory decline observed in dementia. A greater and more specific focus on the combined, rather than isolated, loss of these two critical regions in clinical cases may therefore provide an improved approach to identify at risk cases, to understand the progressive decline of episodic memory and perhaps to encourage better treatments for the key problem of the cortical and subcortical disconnection of the hippocampal system in dementia. 


\section{Transgenic and Lesion Models Are Complementary: Let's Combine Them!}

Transgenic models, especially the use of multiple transgenic mouse lines, have been valuable in studying the progression and interactions of amyloid plaques and NFTs. However, as outlined above, the reported cognitive deficits, $\mathrm{CBF}$ dysfunction and degenerative changes in the entorhinal cortex still fail to reach the severity of the neuropathological and cognitive alterations found in dementia. Conversely, the recent demonstration of the dramatic impact of combined CBF and entorhinal cortex lesions on cognitive abilities brings together two key pieces of the dementia process and points to the value of paying greater attention to the combined changes to these two regions, rather than to either in isolation. However, this new model does not of course mimic the presence of amyloid plaques and NFTs. Single lesions of the CBF fail to induce amyloid plaques in rats, even after a prolonged postsurgical delay [156], but some vascular amyloid deposits have been reported in rabbits [157]. Evidently, transgenic and lesion approaches have generated models which appear complementary. Transgenic mice bearing amyloid plaques and NFTs, but only mild cognitive deficits and modest $\mathrm{CBF}$ and entorhinal cortex alterations on one hand, and lesioned rats reproducing $\mathrm{CBF}$ and entorhinal cortex degeneration and severe memory deficits, but no plaques or NFTs on the other hand. Therefore, we propose that the two approaches be combined by making lesions in both the CBF and the entorhinal cortex in transgenic mice known to robustly exhibit amyloid plaques and NFTs. The resulting model would exhibit dramatic cognitive deficits, histopathological hallmarks and degeneration of two key regions of the disease, in other words, it would show more complete AD pathology than is currently available. Furthermore, we might also predict that the double lesions will not only have an additive effect on the transgenic phenotype, they could also worsen the amyloid and/or tangle burdens. Indeed, there are some indications that lesions of the CBF or the entorhinal cortex influence APP and tau metabolism in their target regions as reported in rabbits and rats [e.g. 157, 158]. Therefore, one might suggest that applying the double lesion to transgenic mice might amplify the amyloid and tangle pathologies. Recent work has suggested a new significance for cholinergic depletion and dementia progression in terms of both tau hyperphosphorylation and the production of $A \beta$; the latter products may in turn disrupt acetylcholine synthesis and cholinergic neurotransmission by altering axon terminals and synaptic integrity
$[15,127]$. Therefore, the proposed lesion plus transgenic model may also help to elucidate how cholinergic dysfunction and entorhinal cortex degeneration interact with the histopathology of the disease. In addition, the extent of the lesions as well as the timing of both entorhinal and CBF lesions could be easily controlled and a wide range of transgenic mouse models of $\mathrm{AD}$ are now available. Thus, this transgenic plus lesion model offers enough flexibility to study behaviorally relevant interactions between the expression of one or more transgenes and the time course of the impact of more or less extensive lesions, both in terms of neuropathology (e.g. enhanced amyloid deposits, increased NFTs, exacerbation of the lesion extent) and cognitive consequences (e.g. potentiation of deficits). Evidence on the influence of basal forebrain or parahippocampal lesions in robust transgenic models is also highly relevant to the evaluation of different therapeutic agents in these genetically compromised animals. For example, the proposed model might be particularly relevant to test new therapeutic strategies, and probably multiple therapies, targeting amyloid plaques and/or NFTs, as well as the symptoms or the progress of two of the key neurodegenerations found in dementia.

One caveat at this point in time that stands against the idea of developing the transgenic plus lesion model is that transgenic and lesion models have been developed in different species, respectively mice and rats. Thus far, there is only one exception in which AD-related genetic manipulations have been performed in the rat [159], whereas the majority of lesion studies have been performed using rats. This difference raises the question of whether results from lesion studies in rats can be generalized to mice, but this seems highly likely as it is already accepted that information from rat studies are informative as to the basic neurobiology of learning and memory, including that found in humans. Moreover, it is feasible to perform selective $\mathrm{CBF}$ lesions and entorhinal cortex lesions in mice. Concerning the entorhinal cortex, such lesions have been conducted in mice for some time [e.g. 160]. And there now exists a selective cholinergic immunotoxin claimed to be an equivalent to $192 \mathrm{IgG}$-saporin which is used for rats, namely mu p75-saporin. Although the older version of this murine immunotoxin had some severe drawbacks [161], an improved version of mu p75-saporin is now available (see http://www.atsbio.com/catalog/catalogframe.html). Our first experiment with this improved murine cholinotoxin found that it is able to induce both selective and extensive damage to CBF neurons (medial septum, diagonal band of Broca and nucleus basalis mag- 
nocellularis) and to produce behavioral effects comparable to those described in rats with $192 \mathrm{IgG}$-saporin lesions [162]. Thus, this murine cholinotoxin may be used in transgenic models of $\mathrm{AD}$ to induce selective cholinergic lesions at different developmental time points.

It is also encouraging that the idea of combining lesions with a transgenic approach has already begun. In one study, Heneka et al. [163] showed that DSP-4 lesions of the noradrenergic neurons of the locus coeruleus greatly augmented the development of cortical amyloid pathology in APP23 mice and also exacerbated the cognitive deficits displayed in episodic-like memory tasks. The authors interpreted these findings in relation with the consequences of the lesions on the regulation of intracerebral inflammatory process. More relevant to the emphasis of the current review, Chauhan [164] has found substantially greater impairments after selective mu p75saporin CBF lesions in Tg CRND8 mice, together with increased tau phosphorylation and tangle-like inclusions. These initial observations support the idea of critical interactions between the presence of localized degeneration or injury and the expression of the transgene(s). It seems highly likely, then, that lesions of the CBF and the entorhinal cortex will produce larger cognitive deficits in transgenic mouse models than in unlesioned transgenic mice. The developmental timing of the lesion intervention in the transgenic mice is likely to be critical, as there may be very different answers that may vary as a function of the specific issue under question. For example, the double lesion could be made before the onset of plaques or NFTs to examine if they accelerate the expression of the transgene. Alternatively, the lesion could be performed only once the plaque or NFT burden is already high (more advanced age) to investigate whether the presence of the latter exacerbates existing memory deficits or induces new ones. In line with the progression of dementia pathology, the lesions could be made in series, starting with the entorhinal cortex and adding the cholinergic one only later.

\section{Acknowledgements}

The authors acknowledge funding by the CNRS and the ULP. J.C.D.-A. has been supported during his stay in Strasbourg as an invited professor by ULP. The authors would also like to thank the Fédération pour la Recherche sur le Cerveau for providing research funds.

\section{References}

1 Alzheimer A: Über eine eigenartige Erkrankung der Hirnrinde. Allg Zschr Psychiatr Psychisch Gerichtl Mediz 1907;64:146148.

2 Hardy J: The relationship between amyloid and tau. J Mol Neurosci 2003;20:203-206.

-3 Monaco S, Zanusso G, Mazzucco S, Rizzuto $\mathrm{N}$ : Cerebral amyloidoses: molecular pathways and therapeutic challenges. Curr Med Chem 2006;13:1903-1913.

4 Fleischman DA, Gabrieli J: Long-term memory in Alzheimer's disease. Curr Opin Neurobiol 1999;9:240-244.

5 Tiraboschi P, Hansen LA, Thal LJ, CoreyBloom J: The importance of neuritic plaques and tangles to the development and evolution of AD. Neurology 2004;62: 1984-1989.

-6 Terry RD, Masliah E, Salmon DP, Butters N, DeTeresa R, Hill R, Hansen LA, Katzman R: Physical basis of cognitive alterations in Alzheimer's disease: synapse loss is the major correlate of cognitive impairment. Ann Neurol 1991;30:572-580.

7 Bowen DM, Smith CB, White P, Davison AN: Neurotransmitter-related enzymes and indices of hypoxia in senile dementia and other abiotrophies. Brain 1976;99:459-496.
8 Davies P, Maloney AJ: Selective loss of central cholinergic neurons in Alzheimer's disease. Lancet 1976;2:1403.

-9 Perry EK, Perry RH, Blessed G, Tomlinson BE: Changes in brain cholinesterases in senile dementia of Alzheimer type. Neuropathol Appl Neurobiol 1978;4:273-277.

10 Baskin DS, Browning JL, Pirozzolo FJ, Korporaal S, Baskin JA, Appel SH: Brain choline acetyltransferase and mental function in Alzheimer disease. Arch Neurol 1999;56: 1121-1123.

11 Frolich L: The cholinergic pathology in Alzheimer's disease - discrepancies between clinical experience and pathophysiological findings. J Neural Transm 2002;109:10031013.

12 Minger SL, Esiri MM, McDonald B, Keene J, Carter J, Hope T, Francis PT: Cholinergic deficits contribute to behavioral disturbance in patients with dementia. Neurology 2000; 55:1460-1467.

13 Pappas BA, Bayley PJ, Bui BK, Hansen LA, Thal LJ: Choline acetyltransferase activity and cognitive domain scores of Alzheimer's patients. Neurobiol Aging 2000;21:11-17.
14 Terry AV Jr, Buccafusco JJ: The cholinergic hypothesis of age and Alzheimer's diseaserelated cognitive deficits: recent challenges and their implications for novel drug development. J Pharmacol Exp Ther 2003;306: 821-827.

15 Mesulam M: The cholinergic lesion of Alzheimer's disease: pivotal factor or side show? Learn Mem 2004;11:43-49.

16 Parent MB, Baxter MG: Septohippocampal acetylcholine: involved in but not necessary for learning and memory? Learn Mem 2004; 11:9-20.

17 Bartus RT, Dean RL III, Beer B, Lippa AS: The cholinergic hypothesis of geriatric memory dysfunction. Science 1982;217: 408-414.

18 Knopman DS, Boeve BF, Petersen RC: Essentials of the proper diagnoses of mild cognitive impairment, dementia, and major subtypes of dementia. Mayo Clin Proc 2003;78: 1290-1308.

19 Kaufer DI: Pharmacologic therapy of dementia with Lewy bodies. J Geriatr Psychiatry Neurol 2002;15:224-232.

20 Lleo A, Greenberg SM, Growdon JH: Current pharmacotherapy for Alzheimer's disease. Annu Rev Med 2006;57:513-533. 
21 Courtney C, Farrell D, Gray R, Hills R, Lynch L, Sellwood E, Edwards S, Hardyman W, Raftery J, Crome P, Lendon C, Shaw H, Bentham P: Long-term donepezil treatment in 565 patients with Alzheimer's disease (AD2000): randomised double-blind trial. Lancet 2004;363:2105-2115.

-22 Doody RS, Stevens JC, Beck C, Dubinsky RM, Kaye JA, Gwyther L, Mohs RC, Thal LJ, Whitehouse PJ, DeKosky ST, Cummings JL: Practice parameter: management of dementia (an evidence-based review). Report of the Quality Standards Subcommittee of the American Academy of Neurology. Neurology 2001;56:1154-1166.

23 Davis KL, Mohs RC, Marin D, Purohit DP, Perl DP, Lantz M, Austin G, Haroutunian V: Cholinergic markers in elderly patients with early signs of Alzheimer disease. JAMA 1999;281:1401-1406.

24 Hardy J, Duff K, Hardy KG, Perez-Tur J, Hutton M: Genetic dissection of Alzheimer's disease and related dementias: amyloid and its relationship to tau. Nat Neurosci 1998;1: 355-358.

25 Van Dam D, D’Hooge R, Staufenbiel M, Van Ginneken C, Van Meir F, De Deyn PP: Agedependent cognitive decline in the APP23 model precedes amyloid deposition. Eur J Neurosci 2003;17:388-396.

-26 DeKosky ST, Ikonomovic MD, Styren SD, Beckett L, Wisniewski S, Bennett DA, Cochran EJ, Kordower JH, Mufson EJ: Upregulation of choline acetyltransferase activity in hippocampus and frontal cortex of elderly subjects with mild cognitive impairment. Ann Neurol 2002;51:145-155.

27 Braak H, Braak E: Entorhinal-hippocampal interaction in mnestic disorders. Hippocampus 1993;3:239-246.

28 Apostolova LG, Dutton RA, Dinov ID, Hayashi KM, Toga AW, Cummings JL, Thompson PM: Conversion of mild cognitive impairment to Alzheimer disease predicted by hippocampal atrophy maps. Arch Neurol 2006;63:693-699.

-29 Bell-McGinty S, Lopez OL, Meltzer CC, Scanlon JM, Whyte EM, Dekosky ST, Becker JT: Differential cortical atrophy in subgroups of mild cognitive impairment. Arch Neurol 2005;62:1393-1397.

- 30 Hirao K, Ohnishi T, Matsuda H, Nemoto K, Hirata Y, Yamashita F, Asada T, Iwamoto T: Functional interactions between entorhinal cortex and posterior cingulate cortex at the very early stage of Alzheimer's disease using brain perfusion single-photon emission computed tomography. Nucl Med Commun 2006;27:151-156.

- 31 Masdeu JC, Zubieta JL, Arbizu J: Neuroimaging as a marker of the onset and progression of Alzheimer's disease. J Neurol Sci 2005;236:55-64.

32 Rodrigue KM, Raz N: Shrinkage of the entorhinal cortex over five years predicts memory performance in healthy adults. J Neurosci 2004;24:956-963.
-33 Stoub TR, Bulgakova M, Leurgans S, Bennett DA, Fleischman D, Turner DA, deToledoMorrell L: MRI predictors of risk of incident Alzheimer disease: a longitudinal study. Neurology 2005;64:1520-1524.

34 Whitwell JL, Przybelski SA, Weigand SD, Knopman DS, Boeve BF, Petersen RC, Jack CR Jr: 3D maps from multiple MRI illustrate changing atrophy patterns as subjects progress from mild cognitive impairment to Alzheimer's disease. Brain 2007;130:17771786.

35 Stoub TR, deToledo-Morrell L, Stebbins GT, Leurgans S, Bennett DA, Shah RC: Hippocampal disconnection contributes to memory dysfunction in individuals at risk for Alzheimer's disease. Proc Natl Acad Sci USA 2006;103:10041-10045.

36 Nestor PJ, Fryer TD, Hodges JR: Declarative memory impairments in Alzheimer's disease and semantic dementia. Neuroimage 2006; 30:1010-1020.

37 LaFerla FM, Oddo S: Alzheimer's disease: Abeta, tau and synaptic dysfunction. Trends Mol Med 2005;11:170-176.

38 McGowan E, Eriksen J, Hutton M: A decade of modeling Alzheimer's disease in transgenic mice. Trends Genet 2006;22:281-289.

39 Spires TL, Hyman BT: Transgenic models of Alzheimer's disease: learning from animals. NeuroRx 2005;2:423-437.

40 Billings LM, Oddo S, Green KN, McGaugh JL, LaFerla FM: Intraneuronal Abeta causes the onset of early Alzheimer's disease-related cognitive deficits in transgenic mice. Neuron 2005;45:675-688.

-41 Dodart JC, Mathis C, Bales KR, Paul SM: Does my mouse have Alzheimer's disease? Genes Brain Behav 2002;1:142-155.

-42 Hsia AY, Masliah E, McConlogue L, Yu GQ, Tatsuno G, Hu K, Kholodenko D, Malenka RC, Nicoll RA, Mucke L: Plaque-independent disruption of neural circuits in Alzheimer's disease mouse models. Proc Natl Acad Sci USA 1999;96:3228-3233.

43 Lewis J, Dickson DW, Lin WL, Chisholm L, Corral A, Jones G, Yen SH, Sahara N, Skipper L, Yager D, Eckman C, Hardy J, Hutton M, McGowan E: Enhanced neurofibrillary degeneration in transgenic mice expressing mutant tau and APP. Science 2001;293:14871491.

44 Ohno M, Sametsky EA, Younkin LH, Oakley H, Younkin SG, Citron M, Vassar R, Disterhoft JF: BACE1 deficiency rescues memory deficits and cholinergic dysfunction in a mouse model of Alzheimer's disease. Neuron 2004;41:27-33.

45 German DC, Eisch AJ: Mouse models of Alzheimer's disease: insight into treatment. Rev Neurosci 2004;15:353-369.
46 Sturchler-Pierrat C, Abramowski D, Duke $\mathrm{M}$, Wiederhold $\mathrm{KH}$, Mistl C, Rothacher S, Ledermann B, Burki K, Frey P, Paganetti PA, Waridel C, Calhoun ME, Jucker M, Probst A, Staufenbiel M, Sommer B: Two amyloid precursor protein transgenic mouse models with Alzheimer disease-like pathology. Proc Natl Acad Sci USA 1997;94:1328713292.

47 Phinney AL, Deller T, Stalder M, Calhoun ME, Frotscher M, Sommer B, Staufenbiel M, Jucker M: Cerebral amyloid induces aberrant axonal sprouting and ectopic terminal formation in amyloid precursor protein transgenic mice. J Neurosci 1999; 19:85528559.

-48 Roder S, Danober L, Pozza MF, Lingenhoehl $\mathrm{K}$, Wiederhold KH, Olpe HR: Electrophysiological studies on the hippocampus and prefrontal cortex assessing the effects of amyloidosis in amyloid precursor protein 23 transgenic mice. Neuroscience 2003;120: 705-720.

-49 Boncristiano S, Calhoun ME, Howard V, Bondolfi L, Kaeser SA, Wiederhold KH, Staufenbiel M, Jucker M: Neocortical synaptic bouton number is maintained despite robust amyloid deposition in APP23 transgenic mice. Neurobiol Aging 2005;26:607-613.

-50 Boncristiano S, Calhoun ME, Kelly PH, Pfeifer M, Bondolfi L, Stalder M, Phinney AL, Abramowski D, Sturchler-Pierrat C, Enz A, Sommer B, Staufenbiel M, Jucker M: Cholinergic changes in the APP23 transgenic mouse model of cerebral amyloidosis. J Neurosci 2002;22:3234-3243.

51 Van Dam D, Marescau B, Engelborghs S, Cremers T, Mulder J, Staufenbiel M, De Deyn PP: Analysis of cholinergic markers, biogenic amines, and amino acids in the CNS of two APP overexpression mouse models. Neurochem Int 2005;46:409-422.

52 Bondolfi L, Calhoun M, Ermini F, Kuhn HG, Wiederhold KH, Walker L, Staufenbiel M, Jucker M: Amyloid-associated neuron loss and gliogenesis in the neocortex of amyloid precursor protein transgenic mice. J Neurosci 2002;22:515-522.

- 53 Calhoun ME, Wiederhold KH, Abramowski D, Phinney AL, Probst A, Sturchler-Pierrat C, Staufenbiel M, Sommer B, Jucker M: Neuron loss in APP transgenic mice. Nature 1998;395:755-756.

54 Kelly PH, Bondolfi L, Hunziker D, Schlecht HP, Carver K, Maguire E, Abramowski D, Wiederhold KH, Sturchler-Pierrat C, Jucker M, Bergmann R, Staufenbiel M, Sommer B: Progressive age-related impairment of cognitive behavior in APP23 transgenic mice. Neurobiol Aging 2003;24:365-378.

- 55 Van Dam D, D’Hooge R, Staufenbiel M, Van Ginneken C, Van Meir F, De Deyn PP: Agedependent cognitive decline in the APP23 model precedes amyloid deposition. Eur J Neurosci 2003; 17:388-396. 
56 Van Dam D, Abramowski D, Staufenbiel M, De Deyn PP: Symptomatic effect of donepezil, rivastigmine, galantamine and memantine on cognitive deficits in the APP23 model. Psychopharmacology (Berl) 2005; 180: 177-190.

-57 Vloeberghs E, Van Dam D, D’Hooge R, Staufenbiel M, De Deyn PP: APP23 mice display working memory impairment in the plus-shaped water maze. Neurosci Lett 2006; 407:6-10.

58 Hellweg R, Lohmann P, Huber R, Kuhl A, Riepe MW: Spatial navigation in complex and radial mazes in APP23 animals and neurotrophin signaling as a biological marker of early impairment. Learn Mem 2006;13:63-71.

- 59 Prut L, Abramowski D, Krucker T, Levy CL, Roberts AJ, Staufenbiel M, Wiessner C: Aged APP23 mice show a delay in switching to the use of a strategy in the Barnes maze. Behav Brain Res 2007;179:107-110.

-60 Hartman RE, Izumi Y, Bales KR, Paul SM, Wozniak DF, Holtzman DM: Treatment with an amyloid-beta antibody ameliorates plaque load, learning deficits, and hippocampal long-term potentiation in a mouse model of Alzheimer's disease. J Neurosci 2005;25: 6213-6220.

-61 Irizarry MC, Soriano F, Mcnamara M, Page KJ, Schenk D, Games D, Hyman BT: Abeta deposition is associated with neuropil changes, but not with overt neuronal loss in the human amyloid precursor protein V717F (PDAPP) transgenic mouse. J Neurosci 1997; 17:7053-7059.

62 Masliah E, Sisk A, Mallory M, Games D: Neurofibrillary pathology in transgenic mice overexpressing V717F beta-amyloid precursor protein. J Neuropathol Exp Neurol 2001;60:357-368.

-63 Reilly JF, Games D, Rydel RE, Freedman S, Schenk D, Young WG, Morrison JH, Bloom FE: Amyloid deposition in the hippocampus and entorhinal cortex: quantitative analysis of a transgenic mouse model. Proc Natl Acad Sci USA 2003; 100:4837-4842.

64 Dodart JC, Meziane H, Mathis C, Bales KR, Paul SM, Ungerer A: Behavioral disturbances in transgenic mice overexpressing the V717F beta-amyloid precursor protein. Behav Neurosci 1999;113:982-990.

-65 Dodart JC, Mathis C, Saura J, Bales KR, Paul SM, Ungerer A: Neuroanatomical abnormalities in behaviorally characterized APP(V717F) transgenic mice. Neurobiol Dis 2000;7:71-85.

66 Gonzalez-Lima F, BerndtJD, VallaJE, Games D, Reiman EM: Reduced corpus callosum, fornix and hippocampus in PDAPP transgenic mouse model of Alzheimer's disease. Neuroreport 2001;12:2375-2379.

-67 Valla J, Schneider LE, Gonzalez-Lima F, Reiman EM: Nonprogressive transgene-related callosal and hippocampal changes in PDAPP mice. Neuroreport 2006;17:829-832.
68 Redwine JM, Kosofsky B, Jacobs RE, Games D, Reilly JF, Morrison JH, Young WG, Bloom FE: Dentate gyrus volume is reduced before onset of plaque formation in PDAPP mice: a magnetic resonance microscopy and stereologic analysis. Proc Natl Acad Sci USA 2003; 100:1381-1386.

69 Weiss C, Venkatasubramanian PN, Aguado AS, Power JM, Tom BC, Li L, Chen KS, Disterhoft JF, Wyrwicz AM: Impaired eyeblink conditioning and decreased hippocampal volume in PDAPP V717F mice. Neurobiol Dis 2002;11:425-433.

70 Lanz TA, Carter DB, Merchant KM: Dendritic spine loss in the hippocampus of young PDAPP and Tg2576 mice and its prevention by the ApoE2 genotype. Neurobiol Dis 2003 . 13:246-253.

71 German DC, Nelson O, Liang F, Liang CL, Games D: The PDAPP mouse model of Alzheimer's disease: locus coeruleus neuronal shrinkage. J Comp Neurol 2005;492: 469-476.

72 Donovan MH, Yazdani U, Norris RD, Games D, German DC, Eisch AJ: Decreased adult hippocampal neurogenesis in the PDAPP mouse model of Alzheimer's disease. J Comp Neurol 2006;495:70-83.

73 German DC, Yazdani U, Speciale SG, Pasbakhsh P, Games D, Liang CL: Cholinergic neuropathology in a mouse model of Alzheimer's disease. J Comp Neurol 2003;462: 371-381.

74 Bales KR, Tzavara ET, Wu S, Wade MR, Bymaster FP, Paul SM, Nomikos GG: Cholinergic dysfunction in a mouse model of Alzheimer disease is reversed by an anti-A beta antibody. J Clin Invest 2006;116:825-832.

75 Su Y, Ni B: Selective deposition of amyloidbeta protein in the entorhinal-dentate projection of a transgenic mouse model of Alzheimer's disease. J Neurosci Res 1998;53: 177-186.

76 Dodart JC, Bales KR, Gannon KS, Greene SJ, DeMattos RB, Mathis C, DeLong CA, Wu S, Wu X, Holtzman DM, Paul SM: Immunization reverses memory deficits without reducing brain Abeta burden in Alzheimer's disease model. Nat Neurosci 2002;5:452457.

77 Chen G, Chen KS, Knox J, Inglis J, Bernard A, Martin SJ, Justice A, McConlogue L, Games D, Freedman SB, Morris RG: A learning deficit related to age and beta-amyloid plaques in a mouse model of Alzheimer's disease. Nature 2000;408:975-979.

78 Brody DL, Holtzman DM: Morris water maze search strategy analysis in PDAPP mice before and after experimental traumatic brain injury. Exp Neurol 2006; 197:330340.

79 Huitron-Resendiz S, Sanchez-Alavez M, Gallegos R, Berg G, Crawford E, Giacchino JL, Games D, Henriksen SJ, Criado JR: Ageindependent and age-related deficits in visuospatial learning, sleep-wake states, thermoregulation and motor activity in PDAPP mice. Brain Res 2002;928:126-137.
-80 Lesne S, Koh MT, Kotilinek L, Kayed R, Glabe CG, Yang A, Gallagher M, Ashe KH: A specific amyloid-beta protein assembly in the brain impairs memory. Nature 2006;440: 352-357.

81 Hsiao K, Chapman P, Nilsen S, Eckman C, Harigaya Y, Younkin S, Yang F, Cole G: Correlative memory deficits, Abeta elevation, and amyloid plaques in transgenic mice. Science 1996;274:99-102.

82 Tomidokoro Y, Harigaya Y, Matsubara E, Ikeda M, Kawarabayashi T, Shirao T, Ishiguro K, Okamoto K, Younkin SG, Shoji M: Brain Abeta amyloidosis in APPsw mice induces accumulation of presenilin-1 and tau. J Pathol 2001;194:500-506.

83 Dong H, Martin MV, Chambers S, Csernansky JG: Spatial relationship between synapse loss and beta-amyloid deposition in Tg2576 mice. J Comp Neurol 2007;500:311-321.

$84 \mathrm{Hu}$ L, Wong TP, Cote SL, Bell KF, Cuello AC: The impact of Abeta-plaques on cortical cholinergic and non-cholinergic presynaptic boutons in Alzheimer's disease-like transgenic mice. Neuroscience 2003;121: 421-432.

85 Wong TP, Debeir T, Duff K, Cuello AC: Reorganization of cholinergic terminals in the cerebral cortex and hippocampus in transgenic mice carrying mutated presenilin-1 and amyloid precursor protein transgenes. J Neurosci 1999;19:2706-2716.

86 Wenk GL, McGann-Gramling K, HaussWegrzyniak B: The presence of the APP(swe) mutation in mice does not increase the vulnerability of cholinergic basal forebrain neurons to neuroinflammation. Neuroscience 2004;125:769-776.

87 Jacobsen JS, Wu CC, Redwine JM, Comery TA, Arias R, Bowlby M, Martone R, Morrison $\mathrm{JH}$, Pangalos MN, Reinhart PH, Bloom FE: Early-onset behavioral and synaptic deficits in a mouse model of Alzheimer's disease. Proc Natl Acad Sci USA 2006;103:5161-5166.

88 Gau JT, Steinhilb ML, Kao TC, D’Amato CJ, Gaut JR, Frey KA, Turner RS: Stable betasecretase activity and presynaptic cholinergic markers during progressive central nervous system amyloidogenesis in $\operatorname{Tg} 2576$ mice. Am J Pathol 2002;160:731-738.

-89 Apelt J, Kumar A, Schliebs R: Impairment of cholinergic neurotransmission in adult and aged transgenic $\operatorname{Tg} 2576$ mouse brain expressing the Swedish mutation of human beta-amyloid precursor protein. Brain Res 2002;953:17-30.

90 Klingner M, Apelt J, Kumar A, Sorger D, Sabri O, Steinbach J, Scheunemann M, Schliebs R: Alterations in cholinergic and non-cholinergic neurotransmitter receptor densities in transgenic $\mathrm{Tg} 2576$ mouse brain with betaamyloid plaque pathology. Int J Dev Neurosci 2003;21:357-369.

-91 Luth HJ, Apelt J, Ihunwo AO, Arendt T, Schliebs R: Degeneration of beta-amyloid-associated cholinergic structures in transgenic APP SW mice. Brain Res 2003;977:16-22. 
\$2 Zhang B, Veasey SC, Wood MA, Leng LZ, Kaminski C, Leight S, Abel T, Lee VM, Trojanowski JQ: Impaired rapid eye movement sleep in the Tg2576 APP murine model of Alzheimer's disease with injury to pedunculopontine cholinergic neurons. Am J Pathol 2005;167:1361-1369.

-93 Westerman MA, Cooper-Blacketer D, Mariash A, Kotilinek L, Kawarabayashi T, Younkin LH, Carlson GA, Younkin SG, Ashe $\mathrm{KH}$ : The relationship between Abeta and memory in the Tg2576 mouse model of Alzheimer's disease. J Neurosci 2002;22: 1858-1867.

94 Arendash GW, Lewis J, Leighty RE, McGowan E, Cracchiolo JR, Hutton M, Garcia MF: Multi-metric behavioral comparison of APPsw and P301L models for Alzheimer's disease: linkage of poorer cognitive performance to tau pathology in forebrain. Brain Res 2004;1012:29-41.

95 Zhuo JM, Prescott SL, Murray ME, Zhang HY, Baxter MG, Nicolle MM: Early discrimination reversal learning impairment and preserved spatial learning in a longitudinal study of Tg2576 APPsw mice. Neurobiol Aging 2007;28:1248-1257.

96 King DL, Arendash GW, Crawford F, Sterk T, Menendez J, Mullan MJ: Progressive and gender-dependent cognitive impairment in the APP(SW) transgenic mouse model for Alzheimer's disease. Behav Brain Res 1999; 103:145-162.

-97 Morgan D, Diamond DM, Gottschall PE, Ugen KE, Dickey C, Hardy J, Duff K, Jantzen P, DiCarlo G, Wilcock D, Connor K, Hatcher J, Hope C, Gordon M, Arendash GW: A beta peptide vaccination prevents memory loss in an animal model of $\mathrm{Alz}$ heimer's disease. Nature 2000;408:982985.

98 Ognibene E, Middei S, Daniele S, Adriani W, Ghirardi O, Caprioli A, Laviola G: Aspects of spatial memory and behavioral disinhibition in Tg2576 transgenic mice as a model of Alzheimer's disease. Behav Brain Res 2005;156:225-232.

$\checkmark 99$ Hale G, Good M: Impaired visuospatial recognition memory but normal object novelty detection and relative familiarity judgments in adult mice expressing the APPswe Alzheimer's disease mutation. Behav Neurosci 2005;119:884-891.

100 Barnes P, Good M: Impaired Pavlovian cued fear conditioning in Tg2576 mice expressing a human mutant amyloid precursor protein gene. Behav Brain Res 2005;157: 107-117.

101 Gotz J, Chen F, Van Dorpe J, Nitsch RM: Formation of neurofibrillary tangles in P301l tau transgenic mice induced by Abeta 42 fibrils. Science 2001a;293:1491-1495.

-102 Ishihara T, Zhang B, Higuchi M, Yoshiyama Y, Trojanowski JQ, Lee VM: Age-dependent induction of congophilic neurofibrillary tau inclusions in tau transgenic mice. Am J Pathol 2001;158:555-562.
103 Murakami T, Paitel E, Kawarabayashi T, Ikeda M, Chishti MA, Janus C, Matsubara E, Sasaki A, Kawarai T, Phinney AL, Harigaya Y, Horne P, Egashira N, Mishima K, Hanna A, Yang J, Iwasaki K, Takahashi M Fujiwara M, Ishiguro K, Bergeron C, Carlson GA, Abe K, Westaway D, George-Hyslop P, Shoji M: Cortical neuronal and glial pathology in TgTauP301L transgenic mice: neuronal degeneration, memory disturbance, and phenotypic variation. Am J Pathol 2006;169:1365-1375.

104 Pennanen L, Welzl H, D’Adamo P, Nitsch RM, Gotz J: Accelerated extinction of conditioned taste aversion in P301L tau transgenic mice. Neurobiol Dis 2004;15:500509.

105 Gotz J, Chen F, Barmettler R, Nitsch RM: Tau filament formation in transgenic mice expressing P301L tau. J Biol Chem 2001b; 276:529-534.

106 Ramsden M, Kotilinek L, Forster C, Paulson J, McGowan E, SantaCruz K, Guimaraes A, Yue M, Lewis J, Carlson G, Hutton M, Ashe KH: Age-dependent neurofibrillary tangle formation, neuron loss, and memory impairment in a mouse model of human tauopathy (P301L). J Neurosci 2005; 25:10637-10647.

107 Lin WL, Lewis J, Yen SH, Hutton M, Dickson DW: Filamentous tau in oligodendrocytes and astrocytes of transgenic mice expressing the human tau isoform with the P301L mutation. Am J Pathol 2003;162: 213-218.

108 Berger Z, Roder H, Hanna A, Carlson A, Rangachari V, Yue M, Wszolek Z, Ashe K, Knight J, Dickson D, Andorfer C, Rosenberry TL, Lewis J, Hutton M, Janus C: Accumulation of pathological tau species and memory loss in a conditional model of tauopathy. J Neurosci 2007;27:3650-3662.

109 Pennanen L, Wolfer DP, Nitsch RM, Gotz J: Impaired spatial reference memory and increased exploratory behavior in P301L tau transgenic mice. Genes Brain Behav 2006; 5:369-379.

110 Asuni AA, Boutajangout A, Quartermain D, Sigurdsson EM: Immunotherapy targeting pathological tau conformers in a tangle mouse model reduces brain pathology with associated functional improvements. J Neurosci 2007;27:9115-9129.

111 McGowan E, Sanders S, Iwatsubo T, Takeuchi A, Saido T, Zehr C, Yu X, Uljon S, Wang R, Mann D, Dickson D, Duff K: Amyloid phenotype characterization of transgenic mice overexpressing both mutant amyloid precursor protein and mutant presenilin 1 transgenes. Neurobiol Dis 1999;6:231-244.

112 Takeuchi A, Irizarry MC, Duff K, Saido TC, Hsiao AK, Hasegawa M, Mann DM, Hyman BT, Iwatsubo T: Age-related amyloid beta deposition in transgenic mice overexpressing both Alzheimer mutant presenilin 1 and amyloid beta precursor protein Swedish mutant is not associated with global neuronal loss. Am J Pathol 2000;157:331-339.
113 Urbanc B, Cruz L, Le R, Sanders J, Ashe KH, Duff K, Stanley HE, Irizarry MC, Hyman BT: Neurotoxic effects of thioflavin S-positive amyloid deposits in transgenic mice and Alzheimer's disease. Proc Natl Acad Sci USA 2002;99:13990-13995.

114 Hernandez D, Sugaya K, Qu T, McGowan E, Duff K, McKinney M: Survival and plasticity of basal forebrain cholinergic systems in mice transgenic for presenilin-1 and amyloid precursor protein mutant genes. Neuroreport 2001;12:1377-1384.

115 Dickey CA, Loring JF, Montgomery J, Gordon MN, Eastman PS, Morgan D: Selectively reduced expression of synaptic plasticityrelated genes in amyloid precursor protein + presenilin-1 transgenic mice. J Neurosci 2003;23:5219-5226.

116 Sadowski M, Pankiewicz J, Scholtzova H, Ji Y, Quartermain D, Jensen CH, Duff K, Nixon RA, Gruen RJ, Wisniewski T: Amyloidbeta deposition is associated with decreased hippocampal glucose metabolism and spatial memory impairment in APP/PS1 mice. J Neuropathol Exp Neurol 2004;63:418-428.

117 Gureviciene I, Ikonen S, Gurevicius K, Sarkaki A, van Groen T, Pussinen R, Ylinen A, Tanila H: Normal induction but accelerated decay of LTP in APP + PS1 transgenic mice. Neurobiol Dis 2004;15:188-195.

118 Trinchese F, Liu S, Battaglia F, Walter S, Mathews PM, Arancio O: Progressive agerelated development of Alzheimer-like pathology in APP/PS1 mice. Ann Neurol 2004;55:801-814.

119 Arendash GW, King DL, Gordon MN, Morgan D, Hatcher JM, Hope CE, Diamond DM: Progressive, age-related behavioral impairments in transgenic mice carrying both mutant amyloid precursor protein and presenilin-1 transgenes. Brain Res 2001;891:42-53.

120 Todd RJ, Volmar CH, Dwivedi S, Town T, Crescentini R, Crawford F, Tan J, Mullan M: Behavioral effects of CD40-CD40L pathway disruption in aged PSAPP mice. Brain Res 2004;1015:161-168.

121 Puolivali J, Wang J, Heikkinen T, Heikkila M, Tapiola T, van Groen T, Tanila H: Hippocampal A beta 42 levels correlate with spatial memory deficit in APP and PS1 double transgenic mice. Neurobiol Dis 2002;9: 339-347.

122 Jensen MT, Mottin MD, Cracchiolo JR, Leighty RE, Arendash GW: Lifelong immunization with human beta-amyloid (1-42) protects Alzheimer's transgenic mice against cognitive impairment throughout aging. Neuroscience 2005; 130:667-684.

123 Liu L, Tapiola T, Herukka SK, Heikkila M, Tanila H: Abeta levels in serum, CSF and brain, and cognitive deficits in APP + PS1 transgenic mice. Neuroreport 2003;14:163166. 
124 Gordon MN, King DL, Diamond DM, Jantzen PT, Boyett KV, Hope CE, Hatcher JM, DiCarlo G, Gottschall WP, Morgan D, Arendash GW: Correlation between cognitive deficits and Abeta deposits in transgenic APP+PS1 mice. Neurobiol Aging 2001;22: 377-385.

125 Ribe EM, Perez M, Puig B, Gich I, Lim F, Cuadrado M, Sesma T, Catena S, Sanchez B, Nieto M, Gomez-Ramos P, Moran MA, Cabodevilla F, Samaranch L, Ortiz L, Perez A, Ferrer I, Avila J, Gomez-Isla T: Accelerated amyloid deposition, neurofibrillary degeneration and neuronal loss in double mutant APP/tau transgenic mice. Neurobiol Dis 2005;20:814-822.

-126 Oddo S, Caccamo A, Kitazawa M, Tseng BP, LaFerla FM: Amyloid deposition precedes tangle formation in a triple transgenic model of Alzheimer's disease. Neurobiol Aging 2003a;24:1063-1070.

-127 Oddo S, Caccamo A, Shepherd JD, Murphy MP, Golde TE, Kayed R, Metherate R, Mattson MP, Akbari Y, LaFerla FM: Tripletransgenic model of Alzheimer's disease with plaques and tangles: intracellular Abeta and synaptic dysfunction. Neuron 2003b;39:409-421.

128 Oddo S, Caccamo A, Tran L, Lambert MP, Glabe CG, Klein WL, LaFerla FM: Temporal profile of amyloid-beta (Abeta) oligomerization in an in vivo model of Alzheimer disease. A link between Abeta and tau pathology. J Biol Chem 2006;281:15991604.

129 Chin J, Massaro CM, Palop JJ, Thwin MT, Yu GQ, Bien-Ly N, Bender A, Mucke L: Reelin depletion in the entorhinal cortex of human amyloid precursor protein transgenic mice and humans with Alzheimer's disease. J Neurosci 2007;27:2727-2733.

-130 Janelsins MC, Mastrangelo MA, Oddo S, LaFerla FM, Federoff HJ, Bowers WJ: Early correlation of microglial activation with enhanced tumor necrosis factor-alpha and monocyte chemoattractant protein-1 expression specifically within the entorhinal cortex of triple transgenic Alzheimer's disease mice. J Neuroinflammation 2005;2: 23.

-131 Caccamo A, Oddo S, Billings LM, Green KN, Martinez-Coria H, Fisher A, LaFerla FM: M1 receptors play a central role in modulating AD-like pathology in transgenic mice. Neuron 2006;49:671-682.

132 Billings LM, Green KN, McGaugh JL, LaFerla FM: Learning decreases A beta* 56 and tau pathology and ameliorates behavioral decline in 3xTg-AD mice. J Neurosci 2007;27:751-761.

-133 Clinton LK, Billings LM, Green KN, Caccamo A, Ngo J, Oddo S, McGaugh JL, LaFerla FM: Age-dependent sexual dimorphism in cognition and stress response in the 3xTg-AD mice. Neurobiol Dis 2007;28: $76-82$.
134 Oddo S, Vasilevko V, Caccamo A, Kitazawa M, Cribbs DH, LaFerla FM: Reduction of soluble Abeta and tau, but not soluble Abeta alone, ameliorates cognitive decline in transgenic mice with plaques and tangles. J Biol Chem 2006;281:39413-39423.

135 Caccamo A, Oddo S, Tran LX, LaFerla FM: Lithium reduces tau phosphorylation but not A beta or working memory deficits in a transgenic model with both plaques and tangles. Am J Pathol 2007;170:1669-1675.

136 Chen G, Chen KS, Knox J, Inglis J, Bernard A, Martin SJ, Justice A, McConlogue L, Games D, Freedman SB, Morris RG: A learning deficit related to age and beta-amyloid plaques in a mouse model of Alzheimer's disease. Nature 2000;408:975-979.

137 Ashe KH: Learning and memory in transgenic mice modeling Alzheimer's disease. Learn Mem 2001;8:301-308.

138 Savonenko A, Xu GM, Melnikova T, Morton JL, Gonzales V, Wong MP, Price DL, Tang F, Markowska AL, Borchelt DR: Episodic-like memory deficits in the APPswe/ PS1dE9 mouse model of Alzheimer's disease: relationships to beta-amyloid deposition and neurotransmitter abnormalities. Neurobiol Dis 2005;18:602-617.

139 Aggleton JP, Pearce JM: Neural systems underlying episodic memory: insights from animal research. Philos Trans R Soc Lond B Biol Sci 2001;356:1467-1482.

140 Hernandez D, Sugaya K, Qu T, McGowan E, Duff K, McKinney M: Survival and plasticity of basal forebrain cholinergic systems in mice transgenic for presenilin-1 and amyloid precursor protein mutant genes. Neuroreport 2001;12:1377-1384.

141 Holcomb L, Gordon MN, McGowan E, Yu X, Benkovic S, Jantzen P, Wright K, Saad I, Mueller R, Morgan D, Sanders S, Zehr C, O’Campo K, Hardy J, Prada CM, Eckman C, Younkin S, Hsiao K, Duff K: Accelerated Alzheimer-type phenotype in transgenic mice carrying both mutant amyloid precursor protein and presenilin 1 transgenes. Nat Med 1998;4:97-100.

142 Bronfman FC, Moechars D, Van Leuven F: Acetylcholinesterase-positive fiber deafferentation and cell shrinkage in the septohippocampal pathway of aged amyloid precursor protein London mutant transgenic mice. Neurobiol Dis 2000;7:152-168.

143 Dodart JC, Mathis C, Bales KR, Paul SM, Ungerer A: Early regional cerebral glucose hypometabolism in transgenic mice overexpressing the V717F beta-amyloid precursor protein. Neurosci Lett 1999;277:49-52.

144 Descarries L, Aznavour N, Hamel E: The acetylcholine innervation of cerebral cortex: new data on its normal development and its fate in the hAPP(SW,IND) mouse model of Alzheimer's disease. J Neural Transm 2005;112:149-162.
145 Sarter M, Bruno JP, Givens B: Attentional functions of cortical cholinergic inputs: what does it mean for learning and memory? Neurobiol Learn Mem 2003;80:245256.

146 Wenk GL: The nucleus basalis magnocellularis cholinergic system: one hundred years of progress. Neurobiol Learn Memory 1997;67:85-95.

147 Lehmann O, Grottick AJ, Cassel JC, Higgins GA: A double dissociation between serial reaction time and radial maze performance in rats subjected to 192 IgG-saporin lesions of the nucleus basalis and/or the septal region. Eur J Neurosci 2003;18:651666.

148 Steffenach HA, Witter M, Moser MB, Moser EI: Spatial memory in the rat requires the dorsolateral band of the entorhinal cortex. Neuron 2005;45:301-313.

149 Aggleton J: Identifying cortical inputs to the rat hippocampus that subserve allocentric spatial processes: a simple problem with a complex answer. Hippocampus 2000;10:466-474.

150 Tiraboschi P, Hansen LA, Alford M, Sabbagh MN, Schoos B, Masliah E, Thal LJ, Corey-Bloom J: Cholinergic dysfunction in diseases with Lewy bodies. Neurology 2000;54:407-411.

151 Traissard N, Herbeaux K, Cosquer B, Jeltsch H, Ferry B, Galani R, Pernon A, Majchrzak $\mathrm{M}$, Cassel JC: Combined damage to entorhinal cortex and cholinergic basal forebrain neurons, two early neurodegenerative features accompanying Alzheimer's disease: effects on locomotor activity and memory functions in rats. Neuropsychopharmacology 2007;32:851-871.

152 Baxter MG: Effects of selective immunotoxic lesions on learning and memory. Meth Mol Biol 2001;166:249-265.

153 Wrenn CC, Wiley RG: The behavioral functions of the cholinergic basal forebrain: lessons from 192 igg-saporin. Int J Dev Neurosci 1998;16:595-602.

- 154 Buckner RL, Snyder AZ, Shannon BJ, LaRossa G, Sachs R, Fotenos AF, Sheline YI, Klunk WE, Mathis CA, Morris JC, Mintun MA: Molecular, structural, and functional characterization of Alzheimer's disease: evidence for a relationship between default activity, amyloid, and memory. J Neurosci 2005;25:7709-7717.

155 Celone KA, Calhoun VD, Dickerson BC, Atri A, Chua EF, Miller SL, DePeau K, Rentz DM, Selkoe DJ, Blacker D, Albert MS, Sperling RA: Alterations in memory networks in mild cognitive impairment and Alzheimer's disease: an independent component analysis. J Neurosci 2006;26:1022210231.

156 Thal JJ, Mandel RJ, Terry RD, Buzsaki, Gage FH: Nucleus basalis lesions fail to induce senile plaques in the rat. Exp Neurol 1990;108:88-90. 
157 Ramirez MJ, Heslop KE, Francis PT, Rattray M: Expression of amyloid precursor protein, tau and presenilin RNAs in rat hippocampus following deafferentation lesions. Brain Res 2001;907:222-232.

158 Beach TG, Potter PE, Kuo YM, Emmerling MR, Durham RA, Webster SD, Walker DG, Sue LI, Scott S, Layne KJ, Roher AE: Cholinergic deafferentation of the rabbit cortex: a new animal model of Abeta deposition. Neurosci Lett 2000;283:9-12.

159 Folkesson R, Malkiewicz K, Kloskowska E, Nilsson T, Popova E, Bogdanovic N, Ganten U, Ganten D, Bader M, Winblad B, Benedikz E: A transgenic rat expressing human APP with the Swedish Alzheimer's disease mutation. Biochem Biophys Res Commun 2007;358:777-782.
160 Cho YH, Jaffard R: Spatial location learning in mice with ibotenate lesions of entorhinal cortex or subiculum. Neurobiol Learn Mem 1995;64:285-290.

-161 Berger-Sweeney J, Stearns NA, Murg SL, Floerke-Nashner LR, Lappi DA, Baxter MG: Selective immunolesions of cholinergic neurons in mice: effects on neuroanatomy, neurochemistry, and behavior. J Neurosci 2001;21:8164-8173.
162 Moreau PH, Cosquer B, Jeltsch H, Cassel JC, Mathis C: Neuroanatomical and behavioral effects of a novel version of the cholinergic immunotoxin mu p75-saporin in mice. Hippocampus, in press.

163 Heneka MT, Ramanathan M, Jacobs AH, Dumitrescu-Ozimek L, Bilkei-Gorzo A, Debeir T, Sastre M, Galldiks N, Zimmer A, Hoehn M, Heiss WD, Klockgether T, Staufenbiel M: Locus ceruleus degeneration promotes Alzheimer pathogenesis in amyloid precursor protein 23 transgenic mice. J Neurosci 2006;26:1343-1354.

164 Chauhan NB: Cholinergic immunolesioning produced tangle-like inclusions in TgCRND8 Brain. Abstr Soc Neurosci 2006; 271.8/KK9. 